\title{
Teachers - Being in Control or Being Controlled?
}

\author{
Editorial
}

Teachers find themselves at the heart of historical and contemporary struggles about public education - its purpose, its contents and its means (see e.g., McCulloch, 2011). Many perceived social problems are delegated to schools to be solved by teachers (see e.g., Tröhler, 2016). Inclusion, democratic citizenship, employability, sustainability - to name a few. Teachers must juggle tensions and competing demands bearing upon them. They are entangled in asymmetric and complex power relations, as the ones subjugated to power, but also as the ones exerting power.

At the frontline of public service, they enact the state's mandate of compulsory schooling vis-à-vis students, parents, and the public (see Ball, Maguire, \& Braun, 2012). In state school systems, they are at the end of the formal political-administrative hierarchy tasked with implementing education policy. Yet, the implementation of education policy is anything but straightforward. Teachers must make sense of and position themselves in relation to other actors and their educational demands. Only then can they actively and selectively respond. This creates space for collective as well as individual discretion by teachers.

Whether teacher discretion is desirable or problematic is highly contested. Reforms labelled as 'New Public Management' try to tackle this tension by granting, on the one hand, greater teacher autonomy in some aspects of service delivery. On the other hand, the measurable results of teachers' efforts are assessed and scrutinised more closely (see also Hood, 1991).

As an example, curricula - while not outdated - did not fulfil expectations as tools to determine what and how teachers teach. The limited influence of compulsory curricula on teaching practice has been recognised (see e.g., Boote, 2006). Teachers are able to exercise discretion when adapting or even supplanting abstract curricula in their everyday teaching practice as they see fit. So, arguably, rather than being curriculum-implementers teachers are, in fact, curriculum-makers. More generally, teachers may even be the ultimate education policymakers given their control over the point-of-delivery in the classroom - for good and for bad (see also MaynardMoody \& Portillo, 2010). This has not been without consequences.

Education policy delivery through curricula is certainly out-of-favour nowadays, being rivalled in importance by technologies of measurement and data processing that promise greater knowledge of actual student achievement. Standardised achievement tests shift the balance between educational administrators and frontline teachers - especially when test results are coupled with sanctions and rewards. How does this impact teachers' discretion to flexibly adapt to what is passed down the hierarchy to their local circumstances? If teachers lose (some of) their discretionary space, would that be desirable?

Teachers enjoy some autonomy due to the limited observability of their work (see also Merton, 1957). But what happens if social problems become increasingly operationalised and prescribed as targets that are in turn measured against specific indicators (see also Hopmann, 2008)? How does this affect teachers and their work?

This issue is an invitation to reflect on and debate the desirability and perils of traditional and modern forms of teacher accountability. Adam Poole starts with a piece on Teacher (In)Discretion in International Schools. He highlights that while teachers in international schools are free from state control, other powerful technologies of performativity are at work that impinge on teachers' sense of self.

In the second contribution titled Teacher Agency and the Digital: Empowerment or Control?, Barbara Schulte discusses the relationship between teacher agency and student empowerment. Using the examples of rural and urban Chinese schools, she reveals how in certain contexts strengthened teacher agency may be able to constrain student empowerment.

David Edwards, General Secretary of the teacher union Education International argues for Quality Education and Professional Teachers in the third contribution. He stresses the importance of the personal teacher-student relationship for quality education.

The fourth contribution on the Control of Teachers Under Conditions of Low-Stakes Accountability by Judith Hangartner addresses changing modes of professionalism and control in contrasting accountability arrangements.

In the fifth article, Kwok Kuen Tsang reports of Ideological Disempowerment of Teachers in Hong Kong that makes it more difficult for teachers to find meaning in their work. 
In the sixth and final essay, Nina Hood directs attention to Manifestations of Autonomy and Control in ... New Zealand. She shows how conflicting international reform movements are merged into national education policies ridden with in-built tensions.
Do you want to comment on an article or the whole issue? Please send your reply to editors@oneducation.net. Replies will be processed like invited contributions. This means they will be assessed according to standard criteria of quality, relevance, and civility.

The Editorial Team

\section{References}

Ball, S. J., Maguire, M., \& Braun, A. (2012). How schools do policy: Policy enactments in secondary schools. https://doi.org/10.4324/9780203153185

Boote, D. N. (2006). Teachers' professional discretion and the curricula. Teachers and Teaching: Theory and Practice, 12(4), 461-478. https://doi.org/10.1080/13450600600644319

Hood, C. (1991). A public management for all seasons? Public Administration, 69(1), 3-19. https://doi.org/10.1111/j.14679299.1991.tb00779.x

Hopmann, S. T. (2008). No child, no school, no state left behind: Schooling in the age of accountability. Journal of Curriculum Studies, 40(4), 417-456. https://doi.org/10.1080/00220270801989818

Maynard-Moody, S., \& Portillo, S. (2010). Street-level bureaucracy theory. In R. F. Durant (Ed.), The Oxford handbook of American bureaucracy (pp. 252-277). https://doi.org/10.1093/oxfordhb/9780199238958.003.0011

McCulloch, G. (2011). The struggle for the history of education. https://doi.org/10.4324/9780203828854

Merton, R. K. (1957). The role-set: Problems in sociological theory. The British Journal of Sociology, 8(2), 106-120. https://doi.org/10.2307/587363

Tröhler, D. (2016). Educationalization of social problems and the educationalization of the modern world. In M. A. Peters (Ed.), Encyclopedia of educational philosophy and theory. https://doi.org/10.1007/978-981-287-532-7_8-1

\section{Recommended Citation}

Editorial Team (2019). Teachers - being in control or being controlled? On Education. Journal for Research and Debate, 2(5). https://doi.org/10.17899/on_ed.2019.5.0 